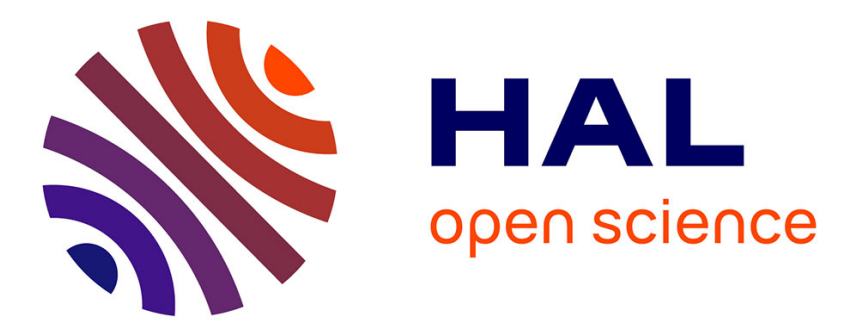

\title{
Agonizing Choices: Tragedy and international relations -A tragic vision of humanitarian intervention in the Bosnian War
}

\author{
Catherine van Offelen, M. L R Smith
}

\section{To cite this version:}

Catherine van Offelen, M. L R Smith. Agonizing Choices: Tragedy and international relations -A tragic vision of humanitarian intervention in the Bosnian War. Review of International Studies, 2020, 46 (4), pp.495-513. 10.1017/S0260210520000121 . hal-03013682

\section{HAL Id: hal-03013682 \\ https://hal.sorbonne-universite.fr/hal-03013682}

Submitted on 19 Nov 2020

HAL is a multi-disciplinary open access archive for the deposit and dissemination of scientific research documents, whether they are published or not. The documents may come from teaching and research institutions in France or abroad, or from public or private research centers.
L'archive ouverte pluridisciplinaire HAL, est destinée au dépôt et à la diffusion de documents scientifiques de niveau recherche, publiés ou non, émanant des établissements d'enseignement et de recherche français ou étrangers, des laboratoires publics ou privés. 


\title{
Agonizing Choices: Tragedy and international relations - A tragic vision of humanitarian intervention in the Bosnian War
}

\author{
Catherine Van Offelen ${ }^{1}$ et M. L. R. Smith ${ }^{2}$ \\ 1University of Bruxelles (ULB) and Sorbonne University in Paris \\ University of Pretoria, South Africa and King's College London
}

\begin{abstract}
Tragedy is one of the oldest metaphorical lenses of international relations. The tragic vision of politics, from Thucydides to contemporary realist theorists, lies at the core of classical realism. However, it is striking how rarely the concept of tragedy has been applied to the discourse of humanitarian intervention. This lacuna is a weakness on both the intellectual and political levels, as nowhere are clashes between competing ethical perspectives more glaring. An examination of the concept of tragedy, as conceived from its Greek origins, can illuminate an understanding of the morally contradictory imperatives created by armed intervention. Using the Bosnian War as a case study, Greek classical tragedy provides a framework to grasp the agonising choices and insoluble ethical dilemmas brought about by humanitarian intervention, in contrast to mere narratives of salvation. The argument conveyed in this article seeks to reconcile a tragic vision with the idea of progress and political action. It concludes by suggesting that the fundamental lessons that lie at the heart of tragedy should be associated with another major concept in Greek culture, namely, the Aristotelian phronesis or 'practical wisdom'.
\end{abstract}

Key words: Tragedy, humanitarian intervention, Ancient Greece, Bosnia, classical realism, practical wisdom

\section{Author biographies, institutional and email addresses:}

1) Catherine Van Offelen is a PhD candidate at the University of Bruxelles (ULB) and at Sorbonne University in Paris. Her research focuses on the notion of 'risk' from Ancient Greece to modern society from a rhetorical perspective. Prior to that, Catherine worked as a security manager for West and Central Africa in an international assistance company, International SOS and Control Risks. She holds a Master's degree in French and Romance Languages and Literatures and a Master's degree in European Studies, both obtained at the ULB, as well as a Master's degree in International Conflict Studies obtained at King's College London.

Email: catherine.van.offelen@ulb.be

Institutional address: ULB, Avenue Franklin Roosevelt 50, 1050 Bruxelles, Belgium

2) M.L.R. Smith is Research Associate in the Office of the Dean of Humanities, University of Pretoria, South Africa and Professor of Strategic Theory at King's College London. Amongst his recent publications are Sacred Violence: Political Religion in a Secular Age (London: Palgrave/Macmillan, 2014) and The Political Impossibility of Modern Counterinsurgency: Strategic Puzzles, Problems and Paradoxes (New York: Columbia University Press, 2015) (both authored with David Martin Jones).

Email:mike.smith@kcl.ac.uk

Institutional address: King's College London, Strand, London WC2R 2LS, UK. 
The notion of tragedy in daily life commonly evokes the idea of supreme misfortune: an epidemic, a fatal accident, or the death of a child. By any standard these are sad events but they are not 'tragic' according to the original conception of the word. Tragedy, as conceived from its Greek origins, stems from the term agon, and refers primarily to a politico-aesthetic where undesirable consequences grow out of struggles over ethical dilemmas. The idea flourished during a short-lived period in Greek theatre in the fifth century BC, when Athens was at the height of its power and prestige. ${ }^{1}$ Every spring, works of playwrights such as Sophocles, Euripides and Aeschylus were performed in amphitheaters near the Acropolis, before thousands of people and in full sight of earth and sky. ${ }^{2}$ More than merely an art form, tragedy was seen as a 'social institution that the city, by establishing competitions in tragedies, set up alongside its political and legal institutions'.3

To qualify as a tragedy, a drama must include a serious miscalculation (hamartia) that brings about a reversal of fortune (peripeteia) and, eventually, a recognition (anagnorisis) in which the hero undergoes 'a change from ignorance to knowledge' and realises their error of judgment. ${ }^{4}$ The tragic genre was barely to last a hundred years. By the first decade of the fourth century BC, 'Athenians had lost a war and an empire, and, perhaps, the inner strength and confidence necessary to confront, let alone relish, critical portrayals of themselves and the human condition'. ${ }^{5}$ No great Greek tragedies were written after the death of Euripides, in about 406BC.

Although the tragic genre in Greek times was short lived, it left a lasting legacy. Tragedy has played a unique role in the self-definition of Western civilization. It is also one of the oldest theoretical lenses of international relations. Since Thucydides' account of the Peloponnesian war, the tragic vision of politics lies at the core of classical realism. ${ }^{6}$ Using the Bosnian war as a case study, this paper explores 
how the concept of tragedy can illuminate an understanding of the dilemmas created by humanitarian intervention. Through the lens of tragedy, it is possible to view human limitations and potentialities when confronted with insoluble ethical predicaments, in contrast to narratives of salvation, which maintain that there is one legitimate course of action and no tragic choices to be made.

Tragedy sheds light upon human frailties, reminding us that the world is filled with contradictions and injustices. ${ }^{7}$ It suggests that chaos always lurks in the undergrowth and that the cycle of bubris (arrogance), bamartia (miscalculation) and nemesis (disaster) is likely to recur for as long as humans exist. It is unsurprising that this notion should have such an appeal to classical realist theorists. ${ }^{8}$ Yet, it is striking how rarely the idea of tragedy has been used in the discourse of human rights and humanitarian intervention. As much as international political theorists are concerned with these issues, they find little place for tragedy in their research. ${ }^{9}$

The act of forceful humanitarian intervention does, however, share common ground with the conception of tragedy, for it involves situations where duties and values are sometimes in radical conflict. Like tragedy, intervention raises compelling questions about ethics and justice, about obedience and values, about rules and order. For example, cosmopolitan understandings often demand that basic human rights be respected everywhere. ${ }^{10}$ Yet the use of force that might be required to save populations from oppression violates other norms that uphold respect for political sovereignty. Whatever is done to rectify perceived acts of wrongdoing invariably opens the floodgates to destruction. Tragedy can thus provide a framework through which the predicaments that are created for actors in the international system - and which cannot be reduced to simple 'right/wrong' binaries - can be evaluated. A 
greater awareness of the tragic vision can enable a better grasp of the dilemmas that these predicaments bring about.

This paper proceeds in three stages. The first section explores the key features of the drama that the Greeks called tragoidia and examines the manner in which the field of international relations handles the concept of tragedy. It is argued that the discourse of humanitarian intervention is largely devoid of a sense of the tragic, and that this lacuna is a weakness on both the intellectual and political levels.

The relevance of tragedy for those concerned with humanitarian intervention can be illustrated by the Bosnian war (1992-1995), which is discussed in the second section. The war can be considered 'tragic' in all senses: from the modern and colloquial understanding of 'dramatic outcome' to the classical plot line associated with bubris, clashing values and unyielding commitment to them, combined with the fundamental flaws of the protagonists. The agonizing choices encountered during the war illustrate the tragic nature of their outcomes, revealing the contours of morally contradictory imperatives with which international actors had to conjure. The chain of events set in train by these contradictions led the situation towards a tragic dénouement. In the end, all were losers. ${ }^{11}$

The final section reflects more broadly on how - and whether - a greater understanding of the tradition of tragedy could help prevent or at least reduce future tragic outcomes. Here we seek to overcome the inertia that might result from the acknowledgement of the tragic dimension of human existence by reconciling its acceptance with the idea of progress and action. The conclusion is that the fundamental lessons that lie at the heart of tragedy should be associated with another major concept in Greek culture, namely, phronesis, an intellectual virtue developed by Aristotle and best translated as 'prudence' or 'practical wisdom'. ${ }^{12}$ 


\section{Understanding tragedy}

When thinking about humanitarian intervention, tragedy is not necessarily the first thing that springs to mind, given this ancient genre might seem closer to poetry than world politics. To determine whether tragedy is an appropriate lens through which to examine international relations will primarily entail returning to a definition of tragedy and its ties with political theory.

Tragedy is a familiar metaphor. Newspapers are filled with terrible things that happen to innocent people who did nothing to deserve their fate. 'Tragic' and 'tragedy' are regularly invoked to punctuate declarations in the face of seemingly inexplicable suffering. Epidemics and wars, floods and famine, accidents and natural disasters are customarily referred to as tragic. And this understanding influences how it affects international relations: the everyday, colloquial meaning of terrible things happening to innocent people, based on the assumption that there is no correlation between suffering and justice. While acknowledging this colloquial meaning, we aim to explore a specific, more historical understanding of tragedy; one that has roots in ancient Athens and that may be of particular interest for analysing international relations.

Tragedy is a specific genre of theatre based on human suffering and vulnerability. It has played a unique role in the formation of Western identity. ${ }^{13}$ These plays flourished for a short period in classical antiquity during the second half of the fifth century $\mathrm{BC}$, when Athens was at its most powerful. One of the most influential definitions of tragedy is that presented by Aristotle in his work Poetics, nearly a century after the zenith of Greek drama: tragedy, he explains, is the imitation of action, mimesis praxeos. The philosopher's view has been highly contested and 
discussed extensively in the literature. Aristotle's account of tragic plots is surely too narrow, if we regard the whole history of the drama, and many surviving tragedies do not fit Aristotle's template. ${ }^{14}$ Nevertheless, the purpose of this paper is not revisit these debates or to propose an all-embracing general definition of tragedy. As Peter Euben argues a tragedy is local and particularised. ${ }^{15}$ However, while playwrights and scholars have since reinterpreted the attributes of tragedy, and despite the uniqueness found in each play, much of the literature agrees on a number of constitutive features.

According to Frost, 'at the heart of all tragedy is an ethical agon', a conflict between two equally compelling but incompatible duties. 'To agonize' therefore means to be engaged with an internal struggle, ${ }^{16}$ and understood as 'a contingent conflict of two important obligations, in such a way that no innocent course is available'. ${ }^{17}$ Such conflicts invariably produce lose-lose choices: whatever is done leads to wrongs. Thus, what renders a story tragic is 'the conjunction of the ethical choice made with the consequence of that choice'. ${ }^{18}$ Tragedy is consequence-driven: a tragic account invites an ethical evaluation of the particular relationship between an act and its consequences.

The structure of the drama is also fundamental. To qualify as such, a tragedy must include a great error of judgement or miscalculation (hamartia) on the part of the protagonist. ${ }^{19}$ Miscalculation triggers a chain of events where the ethical choice results in unintended consequences. In striving to protect what is important to them, the protagonists end up destroying it. This major reversal of fortune is what Aristotle called peripeteia, where irony further deepens the meaning of tragedy. The dénouement comes when the characters, realising what has happened, are overwhelmed by sorrow as a consequence of their acts. They experience recognition 
(anagnorisis) in which they comprehend their error and acquire new knowledge. For Aristotle, tragedy arises because the world is full of people and communities with competing ethical views and values and also because of their unbending commitment to them. ${ }^{20}$

Besides ethical dilemmas involving inescapable wrongdoing, Hans Morgenthau sees another cause of tragedy: bubris or the 'sin of pride', which blinds us to the reality of political affairs. ${ }^{21}$ For the Greeks, bubris is a category error. People fall into bubris when they make the mistake of comparing themselves to the gods in the belief that they can transcend inherent human limitations. It is overconfidence in one's judgement and ability to foresee the future and control events. Those who are the most likely to succumb to bubris are usually the powerful: kings and heroes like Creon, Agamemnon and Ajax. Blinded by ambition, they lose sight of the limits of human power and knowledge. In the tragedians' universe, success stimulates appetite for further success and encourages leaders 'to mistake temporary ascendency for a permanent state of affairs'. ${ }^{22}$

\section{Tragedy as a social institution}

Tragedy as a social and political practice is reflected in its etymology. The Greek work tragoidia derives from a contraction of tragos (goat) and eiedein (to sing). It originally refers to a religious ritual conducted to benefit the city where a song was sung before the sacrifice of a goat. ${ }^{23}$ It was an activity whereby important issues were addressed in relation to the health and well-being of the city. Aristotle thus argued that tragedy in its dramatic form plays a central role in society. ${ }^{24}$ Tragedy portrays 'incidents arousing pity and fear', which in turn achieve catharsis, namely, a purging of the soul that releases its deleterious emotions. Central to Aristotle's view of tragedy is 
the emotional response that the suffering of the characters engenders in the audience, along with the relief of such emotions. Viewed from this perspective, tragedy helps restore emotional balance.

Aristotle also depicts the tragic hero as being 'one like ourselves', mirroring a universal condition of human frailty. However, the tragic hero has also generally 'a great reputation and prosperity': he/she, is in some ways better than the average person, and so has farther to fall. ${ }^{25}$ That characters with noble qualities can make tragic mistakes when caught between structures and forces beyond their control signifies that fortune is precarious and adversity affects the mighty and the powerless equally. ${ }^{26}$ Everyone might take wrong turns, yield to impulses and stumble into hamartia. Tragedy allows us, in this sense, to better understand our true selves.

In ancient Greece tragedy was not simply an art form. Rather, as Vernant states, it was 'a social institution that the city, by establishing competitions in tragedies, set up alongside its political and legal institutions'. ${ }^{27} \mathrm{By}$ its form and content, tragedy provided a framework through which the citizen audience could consider critically the public affairs of the city. It was an opportunity to reflect upon the pattern of their lives, the traditions of the city and the dilemmas it faced. At the time, the tragedians were popular and their plays questioned and critiqued every aspect of the city's customs, ideals, aspirations or contradictions: 'they validated the city's institutions and called them into question; reaffirmed its structure of order and pushed the mind beyond that order to face the chaos those structures had exorcised'. ${ }^{28}$

For Athenians, tragedies offered ethical insights and were a source of moral guidance. ${ }^{29}$ Different ethical questions pertain in the modern condition far removed from the circumstances of ancient Athens, where there was not even a Greek word 
for the notion of foreign policy. Yet broad features, such as the precariousness of the human condition, the changing character of rules and values across time or the painful choices in the face of conflicting duties, have remained the same because they are intrinsic to human societies. As such, these plays have the potential to outlive the specific context in which they emerged and can provide insights that transcend time and space because tragedy touches on the essence of what it is to be human. ${ }^{30}$ This genre can even offer, as this paper will suggest, a conceptual 'toolbox' for illustrating ethical challenges of humanitarian intervention as they materialized in the Bosnian War.

\section{Tragedy and political theory}

A commonly held view is that tragedy and political theory exist in opposition, deriving as it does from Plato's critique of poetry in the Republic. ${ }^{31}$ If we turn to modern theorists, however, the continuities between philosophy - or political theory - become apparent, notably with respect to theories of realism. Many scholars such as Morgenthau, Butterfield, Niebuhr, Mearsheimer, Critchley - consider tragedy central to an understanding of international politics. Realism in particular, as Rengger observed, has a sense of the world as 'essentially tragic'. ${ }^{32}$ The anarchical structure of the international system ensures that great powers have little choice but to pursue a strategy of aggressive realism toward each other. The structure of the system is a situation 'which no one consciously designed or intended'. It is genuinely tragic because, as Mearsheimer explains in The Tragedy of Great Power Politics, it can lead to conflicts that no one actually sought. In this respect, so-called offensive realists contend that the world is 'not made for us' but against us; a world which is 'only partially intelligible to human agency and in itself not necessarily well adjusted to 
ethical aspirations'. ${ }^{33}$ Such conclusions do not mean that realists dismiss ethical reasoning, human agency and judgment. Simply, they deem ethical strivings as well as religious and cultural identities as potentially tragic factors in the international system.

Other scholars perceive the potential for tragedy arising from religious, ethical and cultural identities, giving rise to competing cultural and ethical values. In consequence, the potential for tragedy is ubiquitous and 'even if one pattern of behaviour with tragic consequences can be avoided, another is always likely to loom up from beyond the horizon'. ${ }^{34}$ Even so, as this paper will argue, the concept of tragedy also has a political purchase. Instead of establishing this claim within debates over, say, classical realism, where a condition of tragedy is already widely accepted, the argument will make the case in a context where it is rarely used, namely, in debates over humanitarian intervention. Indeed, according to Brown, most of the international political theorists who have addressed this issue 'can find no place for the notion tragedy in their work', 35

\section{Humanitarian intervention: a discourse largely devoid of the tragic}

Humanitarian intervention can be defined as 'the threat or use of force across state borders by a state (or group of states) aimed at preventing or ending widespread and grave violations of the fundamental human rights of individuals other than its own citizens, without the permission of the state within whose territory force is applied'. ${ }^{36}$ Arguments burn fiercely about the legitimacy of forceful humanitarian interventions because they involve a clash of duties. ${ }^{37}$ Some commentators view humanitarian intervention as a moral contradiction: how can armed intervention ever be humanitarian, particularly if it may lead to the death of innocent parties? ${ }^{38}$ The 
understanding that any use of force for purposes other than self-defence or without a specific UN Security Council Mandate is contrary to international law because it violates the duty to respect the right of self-determination compounds such concerns. ${ }^{39}$ Advocates of non-intervention invariably assert the sovereignty principle on the basis that humans 'create their own meaningful community within sovereign states'. ${ }^{40}$

Against this, is the assertion of a 'responsibility to protect'. ${ }^{41}$ This principle, backed by the UN General Assembly, proclaims the moral imperative of defending populations against threats of death or extreme oppression. Moreover, this is an imperative that falls on the broader community of nations, especially if states themselves are the perpetrators of the oppression. ${ }^{42}$ For Heinze, this cosmopolitan reasoning possesses 'a more interventionist ethos and tends to perceive state boundaries as having merely a derivative significance'. ${ }^{43}$ Such a standpoint suggests that a state should rightfully be under external scrutiny, and accountable for how it behaves toward its citizens. Furthermore, all participants in the existing global order must therefore be held responsible for any human rights violations and are, as a result, obligated to put an end to these violations by engaging in military intervention if necessary.

Each of these opposing positions makes normative arguments about the undesirability or moral legitimacy of humanitarian interventions. ${ }^{44}$ Interventions are often imbricated in moral ambiguity and cannot straightforwardly be applauded or condemned. As Brown notes, in such situations "to act is to do wrong - and "action" here includes consciously chosen inaction, as in Rwanda in 1994'.45 Both sides of the argument, though, can be said to misinterpret the nature of the problem because 
they ignore the tragic dimension of the choices involved in humanitarian intervention.

An essential question is whether the tragic aspect of the choices involved is recognised in the discourse. For Brown, this is generally not the case. ${ }^{46}$ Whether opponents or proponents of intervention, theorists often tend to cast the problem in binary terms, and see no tragic choices to be made. For example, the absence of a sense of the tragic is illustrated in Charles Beitz's Political Theory and International Relations (1979), in which he explains that that there is no principled reason to abstain from intervening in a foreign country if the local population does not benefit from universal standards of human rights. ${ }^{47}$ His only concern is whether the action might worsen the situation, without apparently discerning that behind such narratives of salvation, there might actually be a clash of values and duties involved. Michael Walzer, on the other hand, does implicitly perceive the tragic essence of the choices involved in political action. While Walzer does not employ the word 'tragic' he nevertheless articulates the problem in terms of 'dirty hands', which shares with tragedy the fundamental understanding that sometimes, whatever the course of action chosen, it involves wrong-doing. This fact cannot be ignored or wished away. ${ }^{48}$

Aside from Walzer, the discourse surrounding humanitarian intervention is largely devoid of a sense of the tragic nature of the dilemmas posed. Theorists frequently approach the problem in Manichean terms, trying to refine away the clashes of incompatible duties. As Brown notes, this absence is intellectually impoverishing and politically debilitating because a crucial aspect of intervention is overlooked - namely, the tragic dilemmas inherent in the very notion of humanitarian intervention. ${ }^{49}$ 


\section{The Tragic Dimension of the Bosnian War: A Humanitarian Perspective}

The very name of Bosnia evokes 'tragedy' in its quotidian sense. The combustion of age-old fratricidal hatreds among Serbs, Croats and Bosnians, ethnic cleansing, mass rape as a tool of war, and civilian massacres, has left its mark on contemporary European history. The war killed almost 100,000 people between 1992 and 1995, and resulted in some 2.2 million displaced persons, making it the bloodiest conflict on European soil since World War II. ${ }^{50}$ The suffering and misery behind the statistics is harder to quantify but, at heart, Bosnia was a humanitarian catastrophe.

Forceful humanitarian interventions have multiplied over the past 20 years ${ }^{51}$ but few have aroused as much disillusionment and involved such 'tragic' choices as Bosnia. The Bosnian war confronted Western states with moral dilemmas that hampered the ability to act collectively. ${ }^{52}$ Instead, they played their part in the drama through a series of miscalculations similar to those of ancient Greek spectacle. As for the consequences, the calamity that unfolded created scenes reminiscent of the darkest periods of Europe's history during World War II. Bosnia thus illuminates well the tragic aspects of humanitarian intervention of the kind that ancient Greek theatre sought to accentuate. The following sections do not seek to provide a full and detailed account of the unfolding of the Bosnian war or the international community's action in this region - an impossible task within the confines of an article. ${ }^{53}$ Rather, the intention is to focus on specific aspects and meaningful episodes of the war in order to reveal common features between tragedy and foreign intervention. 


\section{Hubris and the narrative of salvation}

When the European Community (EC) recognised the independence of Slovenia and Croatia from the Federal Republic of Yugoslavia in 1991, it invited the multi-ethnic Socialist Republic of Bosnia and Herzegovina to apply for recognition as well. A referendum on independence was held in 1992 and of the nearly two-thirds of the electorate that went to the polls, almost all voted in favour of independence. The third who did not vote were, broadly, Serbs who boycotted the vote. The referendum, endorsed by the EC in support of the principles of self-determination and sovereignty for the republics, cemented national awakening and aggressive nationalism on all sides. ${ }^{54}$ Bosnia was thus primed for war. As soon as its independence was recognised by the United States and the EC in April 1992, the Bosnian Serbs, supported by the Yugoslav People's Army (JNA) and the Serbian government of Slobodan Milosevic, joined forces to secure what they saw as ethnic Serbian territory. The war spread quickly across the country. Sarajevo and many of the towns in Eastern Bosnia with large Bosnian Muslim (or Bosniak) populations, such as Zvornik, Foča, and Višegrad, were besieged by local Bosnian Serb paramilitary groups and Yugoslav army units. 55

Milosevic's regime aimed to create a 'Greater Serbia'. With the collapse of communism after the end of the Cold War, the notion of exclusive ethnic identification appealed to former communist elites across central and Eastern Europe as a means of political mobilisation. The nationalist option was attractive to many Serbs, who were the largest ethnic group in the six-republic Yugoslav federation.

The ethnic exclusivism of Milosevic and other Serbian leaders resonates with the starting point of many a Greek tragedy, namely, bubris. In Greek tragedies, the 
more emboldened characters become, the more tempted they are to overreach themselves. Overconfidence leads them to embrace dangerous ventures resulting in outcomes that are diametrically opposed to those intended. This is most memorably represented in the character of Oedipus, the tragic hero of the three plays by Sophocles (Oedipus Tyrannos, Oedipus at Colonus and Antigone). At the beginning of the first play, Oedipus is overly confident, and with good reason. He is a consummate problem solver and an outstanding analyst. After all, he was the one who discovered the answer to the riddle of the Sphinx, thereby saving the city of Thebes. His first words in the play reveal his pride: 'Here I am - myself - you all know me, the world knows my fame: I am Oedipus'. ${ }^{56}$ Oedipus seals his fate, however, by displaying a double act of hubris: he arrogantly refuses to step back at the crossroads when he meets an angry stranger, and he 'blindly' believes he can outwit the gods and outrun his fate, despite the warnings of his wife Jocasta. Sophocles was highlighting that bubris is a common human failing. As Diodotus explains in the Mytilenian Debate, people driven by hubris persuade themselves that they will succeed by ignoring or distorting contradictory evidence, before stumbling into ate (self-seduction) and bamartia (error of judgment). ${ }^{57}$

In the sense that bubris applies equally to political organisations and institutions, the international community was also guilty of a distorting self-delusion over Bosnia. The ominous signs after August 1990 of violent clashes in Croatia and open discussions about independence in Slovenia raised concern among diplomats, scholars and intelligence agencies about the danger of the 'Balkanization' and Yugoslavia's disintegration. ${ }^{58}$ These warnings were largely ignored, not because they were unconvincing but because they did not seem to constitute a threat to the interests of the rest of Europe. Since the Soviet Union no longer needed to be 
contained, Yugoslavia's fate was not considered significant. According to Woodward, 'more important than any specific calculations of threat and interest at the time were the general euphoria and self-confidence in the West based on the belief that threats to international security were truly on the decline'. ${ }^{59}$ Political leaders in the European Community were so convinced that the world had changed that they dismissed the warning signs. Like Oedipus, their ebullience made them blind. ${ }^{60}$

\section{The dilemma of intervention}

As the Bosnian war progressed, established conceptions of the European and international order, such as the commitment to the right of self-determination, enshrined in the UN Charter and the Helsinki Accords, came under scrutiny. What, exactly, was the right of peoples to self-determination? Of the nearly two-thirds of the Bosnian population who voted, 99.7 per cent had chosen independence. Did it mean the right of sovereign states to non-interference in their domestic affairs? If so, the actions of Yugoslavia to protect the integrity of its borders were lawful. Did it mean a fundamental right of nations to independence? Was the international community, therefore, obligated to recognise the splitting apart of states, thus overriding the principle of non-interference and the sanctity of borders? Was, in fact, this choice 'a human right', as presented in the Helsinki Final Act? If so, external intervention could be legal and legitimate. But whose choice should be respected? The commitment to the principle of national self-determination and the protection of universal human rights were in radical conflict. Every possible response on the part of the international community was inadequate from a certain point of view, rendering the situation genuinely tragic. 
The European Community chose to ignore the political dilemmas inherent in these contradictory principles with the result that the debates over whether to intervene in Bosnia lacked consistency. Taking military action would have merely transformed a three-sided war into a four-sided one, adding fuel to the raging fire rather than quenching it. Meanwhile, the belief that 'something must be done' to stop the fighting was equally strong. 'Blindly, naively and over-optimistically', as O’Ballance observed, the UN blundered into a 'peace-making' situation for which it was neither conditioned nor capable. ${ }^{61}$

It is important to recognise that deliberations about whether to intervene in a humanitarian crisis are going to be influenced heavily by domestic public opinion. If a government commits grave human rights violations against its own citizens it may be legitimate for external powers to intervene in order to save victims. An outcry from voters can spur leaders into action. But public opinion can be volatile, which sheds light on another tragic aspect of intervention. Once initiated, if progress fails to materialize quickly or if the results differ from those anticipated, public opinion can turn against the intervention.

Brown highlighted how strikingly the rhetoric of 'Something must be done' appeals when people are confronted with obvious examples of tyranny and cruelty. Equally striking, though, is how this support vanishes when something is actually done and the intervention undertaken. The reason for this volatility is not fickleness, but rather the fact that something is missing in the moral and practical narrative. For Brown, 'the original appeal, by failing to acknowledge the moral complexities of the situation, wins a cheap, but transient victory'. ${ }^{62}$ To illustrate, the high volume of media coverage during Bosnian War ensured that 'highly marketable themes such as dramatic bloodshed and sexual violence' were broadcast widely. ${ }^{63}$ Yet, the more the 
scale of the violence and the complexity of the situation was disseminated the more public support for intervening was eroded. The inability of the external powers to act decisively therefore translated itself into a crisis of confidence for the international order. ${ }^{64}$

\section{Miscalculation and hamartia: the 'safe areas' and the massacre of Srebrenica}

When Serbian forces started ethnically to cleanse areas of Central, Eastern and Northern Bosnia, an estimated 2.6 million refugees were forced to flee into enclaves such as Gorazde, Zepa, Tuzla and Sarajevo. ${ }^{65}$ European countries were reluctant to allow the influx of refugees, closing their borders to the Bosnians and imposing visa controls. ${ }^{66}$ The agon facing neighbouring European countries was encapsulated by the UN High Commissioner for Refugees Sadako Ogata, who stated that 'If you take these people, you are an accomplice to ethnic cleansing. If you don't, you are an accomplice to murder'. ${ }^{67}$

The decision taken by the UN that it would provide humanitarian assistance to the civilians trapped in Bosnia led to the creation of 'safe havens'. In April 1993, Resolution 819 established a 'safe area' in Srebrenica and later, Tuzla, Zepa, Sarajevo. Bihac and Gorazde were also declared as 'safe areas'. The hope was that civilians would receive humanitarian assistance and find protection inside Bosnian territory. The safe haven policy, which had been successful in northern Iraq to provide protection to the Kurds, was far less effective in Bosnia and Herzegovina.

The term safe havens, in fact, became a terrible misnomer as they 'were among the most profoundly unsafe places in the world'. ${ }^{68}$ On paper the protection mandate appeared strong, with the backing of potential NATO airstrikes and the provision of some 34,000 troops of the United Nation Protection Force 
(UNPROFOR) to 'obtain deterrence through strength' and to ensure the protection for the safe areas. ${ }^{69}$ In practice, only 7,600 were actually deployed directly in the protection of the safe areas, a number that proved insufficient to the task: a reality confirmed by UN Secretary Boutros Boutros-Ghali who stated that these troops would 'not guarantee the defence of the safe area, but would provide a basic level of deterrence'. ${ }^{70}$

On 11 July 1995, in the worst atrocity of the war, some 8,000 Bosniaks were massacred by Bosnian Serb troops in Srebrenica, which two years before had been declared a UN 'safe area', guarded by some 600 lightly armed Dutch peacekeepers. The predominantly Bosniak area of central Podrinje (the region around Srebrenica) was strategically important to the Serbs in order to secure sufficient territory necessary for the establishment of their new political entity Republika Srpska, the self-proclaimed Serbian republic in Bosnia. Few people had anticipated the savagery that took place. ${ }^{71}$ Far from providing safety, safe areas ended up trapping people who became easy targets for Serb forces. The best of intentions, the creation of safe zones for refugees, revealed itself to be a terrible miscalculation. The term miscalculation is invoked here in the sense understood in Greek tragedy, where hamartia refers to the protagonist's error of judgement that leads to a chain of events culminating in a reversal of fortune..$^{72}$ The notion of miscalculation, whether moral, political or military, thus elucidates human fallibility, which despite the best of endeavours, is unable to fully comprehend or control events. ${ }^{73}$

General Bernard Janvier, the commander of UNPROFOR troops in former Yugoslavia, has often been blamed for letting the massacre of Srebrenica happen by failing to sanction air strikes. However, the individual governments of the UNPROFOR contributing nations also lacked resolve, in particular to risk the lives 
of their soldiers. Janvier found himself in a lose-lose situation. Eventually he elected to prioritise saving the lives of the UN 'blue helmets', thereby allowing the enclave fall into the hands of Bosnian Serb forces. ${ }^{74}$ How could the international community combine a moral duty to save victims from ethnic cleansing with the practical implications of the use of air and ground forces, while ensuring that the moral imperative of not letting aggression pay? Was it even right to send in the blue helmets to set up 'safe areas' if participating governments were themselves unwilling to endanger the lives of their soldiers in the furtherance of protecting the civilian populace of Bosnia in the first place? This - the most fundamental question of all in the Bosnian war - was never resolved. ${ }^{75}$

\section{A cycle of vengeance}

The slaughter at Srebrenica highlights the terrible ironies that are often at the heart of tragedy. The UN/NATO intervention in the Bosnian crisis aimed at the protection of civilians, but instead provided the irreversible turning point in the conflict's escalation toward massacre and ethnic cleansing, setting in train a spiral of vengeance. Revenge is another important theme that emerges from classical Greek understandings of tragedy, which the massacre of Srebrenica illuminates only too well. For the president of the Bosnian Serb administration Radovan Karadzic the massacre in the Srebrenica 'was not a slaughter organized by the army, but revenge attacks by the Bosnian Serbs whose relatives had been killed by Muslims earlier in the war'. $^{76}$

Aeschylus' Oresteia is precisely about revenge, and how public justice is able to restrain the hubris and passions that would otherwise tear societies apart. In the first part of the play, Artemis demands the sacrifice of Agamemnon's daughter 
Iphigenia in order to gain a favourable wind for the Greek fleet in the expedition against Troy. The request leaves Agamemnon torn between two contradictory duties. As the leader of the Greeks, he must do whatever is necessary to win the war against Troy, but his daughter's sacrifice would obviously violate his duty as a father. ${ }^{77}$ Agamemnon handles the tragic choice by deciding to carry out the sacrifice of his daughter. However, his decision triggers an inescapable spiral of vengeance and retaliation. Clytemnestra, Iphigenia's mother, is thrown into despair and avenges the loss of her child by murdering her husband Agamemnon. This murder infuriates the children of Agamemnon, Orestes and Electra, who in turn avenge their father by killing their mother Clytemnestra.

Vengeance is a self-perpetuating cycle. The ancient justice of the Erinyes stated that nothing else can cleanse a bloodstain but more blood. In the Oresteia, this cycle of pain ends only when the matter was brought before Athena's public court of justice and resolved once and for all. Athens, at the time, embraced a new order, where revenge and the destructive nature of human impulses were channelled through the process of civil justice. Interestingly, Aeschylus implies in the Oresteia that tragedies can sometimes enhance, change and facilitate the transition to progress and new political practices.

Hostilities came to an end in Bosnia with the General Framework Agreement for Peace in Bosnia and Herzegovina, also known as the Dayton Agreement, which was negotiated at Wright-Patterson Air Base in Dayton, Ohio and signed in Paris on 14 December 1995. Halting the violence was not easy. As Ignatieff argues: 'the legacy of bitterness in places like Kosovo or Bosnia is so intense that international administration has to remain in place, simply in order to protect minorities from vengeance by the victorious yet previously victimized minority'. ${ }^{78}$ It takes time to end 
a culture of vengeance in shattered communities. It also takes time to restore a political dialogue and social trust between communities ravaged by ethnic conflict. The peace in Bosnia remains fragile, but so far the negotiated agreement has been able to restore a degree of stability and human rights, with several scholars discerning that it constitutes an effective example of conflict resolution. ${ }^{79}$ With the International Criminal Tribunal for the former Yugoslavia (ICTY) war crimes can be prosecuted,${ }^{80}$ thereby fulfilling the potential for public justice, as pre-figured in Greek tragedy, to arrest the possibility of the cycle of vengeance from resurfacing.

\section{The final curtain and tragic recognition (anagnorisis)}

It was difficult for the UN to ignore its role in the Bosnian tragedy and the fall of the Srebrenica enclave in particular. In 1999, the General Assembly published the 'Report of the Secretary General Pursuant to General Assembly Resolution 53/35: The Fall of Srebrenica'. The conclusion of the 113 pages report takes the form of an anagnorisis, a recognition of past errors of judgement and their painful consequences:

The United Nations experience in Bosnia was one of the most difficult in our history. Through error, misjudgement and an inability to recognize the scope of evil confronting us, we failed to do our part to save the people of Srebrenica from the Serb campaign of mass murder. Srebrenica crystallized a truth understood only too late by the United Nations and the world at large: that Bosnia was as much a moral cause as a military conflict. The tragedy will haunt our history forever. ${ }^{81}$ 
Recognition comes when the character realises the actual situation and sees things as they stand. At the heart of anagnorisis is the discovery of one's identity or true nature, but this new knowledge or insight is often gained at the price of considerable suffering. This is the case of Oedipus in Sophocles' Oedipus Tyrannos. He manages to find the answer to the riddle of the Sphinx and so it seems plausible to assume that he will solve the second riddle of the play, 'Who killed Laius?' He does indeed, but the price to pay is terrible. In his search for the truth, Oedipus comes to the realisation that he was the one who had murdered the late king of Thebes, Laius, who was also his biological father, and that he has unwittingly married his own mother. When he is calling for a merciless punishment against Laius' killer he is condemning himself unknowingly.

Oedipus' tragedy points directly to the problem of limited self-knowledge. Oedipus is ignorant about his own identity but when the awful truth finally becomes clear and he sees the darkness of his actions, he blinds himself by putting out his eyes. Many years later, the Oedipus we find in Oedipus at Colonnus has reflected on his fate and undergone a transformation. His blindness has paradoxically led to clearer vision and his hubris has turned into prudence. In the tragedian's universe, immense value is placed on the attempt to find answers to the most fundamental questions of existence. It is Oedipus asking, 'Who am I?' - perhaps the most basic existential question of all - and the endeavour to find self-knowledge in those answers that constitutes the bedrock of gaining insight through tragedy. Since the war of 1992-1995 and the failed intervention, the Bosnian state and the international community have been engaged in just such an exercise. 


\section{Tragedy and fate}

The international involvement in Bosnia was 'tragic' in all senses, both in terms of the destruction wrought on the populations involved, and in the classical sense of tragedy, as a drama the consequences of which are of important moral significance. The plans, ideals and hopes of the protagonists were always likely to be overturned by errors of judgement and tragic flaws: part of this tragic story has been one of bubris and blindness, of dilemma and miscalculation, of honourable intentions leading to destructive outcomes. Here the notion of tragedy can be deployed as a conceptual tool or an epistemological basis for analysing intervention. Hubris, hamartia, peripeteia, agon, irony, nemesis, anagnorisis and other tragic concepts can enrich both our analytical understanding and vocabulary in complex ethical challenges by framing them differently.

However, this raises another fundamental question - namely, that of the ineluctability of fate. Was the humanitarian tragedy in Bosnia bound to happen? The 'tragic vision', as offensive realists are inclined to interpret the concept suggests a belief in historical inevitability. A narrow account of tragedy as merely historical fatalism deprives the concept of its theoretical and political utility, and discounts the possibilities of human agency. The aim of this analysis, though, is to reconcile the acceptance of tragedy in human existence with the idea of progress, optimism and collective political action: what the Greeks called praxis.

\section{Reconciling tragedy and progress: practical wisdom and vigilant intervention}

In the classical sense, humanitarian interventions will always be tragic because they involve inescapable dilemmas. There is a moral 'responsibility to protect' civilians from atrocities perpetrated by state or non-state actors. Yet, the use of military force 
in circumstances other than self-defence jeopardises the lives of those participating in the intervention, violates the sovereignty of local communities, and risks the deaths of non-combatants. The quandaries of intervention are therefore intrinsically tragic.

The scope of tragedy in relation to humanitarian intervention ultimately raises the question of fate and political action. Considering the tragic dimension of the choices involved in armed humanitarian actions, one might wonder whether such interventions should simply be avoided altogether?82 The 'tragic vision', as interpreted by offensive realists, reflects a form of pessimism. It submits that the world is structured fundamentally against the ethical strivings of human beings or that these inevitably produce negative outcomes. Such a view tends to discount ethical reasoning, human agency and political judgment. However, Lu's understanding of the tragedian universe as being characterized by 'the indeterminacy of human (ethical) agency, rather than its futility or irrelevance', might suggest itself as a less pessimistic appreciation of the tragic dimensions of human affairs. ${ }^{83}$

The acceptance of the tragic dimension of intervention does not have to rhyme with either passivity or fatalism. A narrow account of tragedy as merely historical fatalism deprives the genre of its insights into political analysis. Historical fatalism namely, that disasters are bound to happen and nothing good can come from trying to do something about them - is an uninstructive lesson. As Bill Clinton stated during his electoral campaign in August 1992: 'If the horror of the Holocaust taught us anything, it is the high cost of remaining silent and paralyzed in the face of genocide'. ${ }^{84}$ Fatalism, then, should not be the key observation to be extracted from the tragic vision; rather, it is the capacity to enhance judgment and wisdom with a view to reconciling tragedy with the idea of action in human conduct. 


\section{Phronesis and action in human conduct}

Greek tragedy reveals the generally adverse consequences of the unyielding commitment to normative ideals. In Sophocles' play Antigone, the eponymous character is portrayed as a heroine who is loyal to her brother, but whose stubbornness in pursuit of her familial duty brings her into conflict with Creon, the King of Thebes, who is just as committed to sustain civic order. Tragic conflicts arise not only because agents have contradictory duties and values, but also because of their implacable, blind commitment to them. Creon and Antigone are unable to empathize with one another and fail to accept their mutual duties or to develop empathy, with destructive outcomes not only for themselves, but also for their family and the City. 85

The Greek concept of phronesis offers a practical rather than normative approach to moral dilemmas, as they emerge in tragedies and humanitarian intervention alike. Best translated as 'practical wisdom', phronesis is one of the three 'virtues of thought' distinguished by Aristotle. ${ }^{86}$ The first of these, techne (art or craft knowledge), is essentially about the work of a technician or a craftsman and involves instrumental reason. Episteme (theoretical or scientific knowledge) relates to sciences and 'things that cannot be otherwise ${ }^{87}$ - a kind of knowledge that has little relevance in the fluctuant and contingent realm of human affairs. For Aristotle phronesis is a focus on prudence or practical wisdom, which he perceived as the most important intellectual virtue in considering human and political action in the polis. 88

Aristotle defines phronesis as a 'true and reasoned state of capacity to act with regard to the things that are good or bad for man'. ${ }^{89}$ It is a virtue or developed ability that enables the individual to judge with insight, make good decisions and carry out 
these decisions successfully. Unlike episteme, it tackles things that 'could be otherwise'. Phronesis, then, involves effective deliberation, considering the circumstances and discerning the appropriate course of action.

At the heart of practical wisdom is the ability to reason well and go through the steps that are needed to apprehend a given situation. The 'prudent' person (phronimos) is aware of nuances and is capable of flexibility when making decisions. He or she reconciles virtue and experience, intuition and rigour, lucidity and practical skill..$^{90}$ This is why phronesis is at the heart of public life: the good policy-maker - just like the good doctor, the skilful military strategist or the experienced navigator - is typically able to exhibit this prudence. On this account, Pericles and men of that kind can be considered as epitomes of phronesis 'because they discern what is good for themselves and good for mankind'. ${ }^{91}$ And yet, as Aubenque explains, Pericles is not a 'beautiful mind'. ${ }^{92} \mathrm{He}$ is neither an idealist nor a Machiavelli, but a man who knows how to cope with uncertainty and contingency, able to see and decide relatively quickly what course of action to take in the complexity of reality.

What remains of this phronesis today? This concept is somewhat different from the modern conception of prudence. Neither of the usual translations such as 'prudence' or 'practical wisdom' entirely captures the essence of this virtue. The lacuna is interesting, and perhaps revealing of a feature of modern society, overwhelmingly concerned with theoretical knowledge (episteme) to the detriment of practical judgement. Indeed, prudence today equates to caution and carefulness, in the vein of the Latin adage 'Primum non nocere'. Government leaders often call for prudence, which usually means avoiding taking action in the face of a difficult or controversial problem. But as Westberg discerns, this is 'a miserable sort of prudence, self-protective, preferring safety to change', far removed from what 
Aristotle had in mind. ${ }^{3}$ Phronesis is itself an end, namely, the 'good action' in the pursuit of the good life in a well-functioning polis. ${ }^{94}$ Here it is imperative to stress that phronesis is primarily concerned with action, for it is a practical virtue. Outcome is all: if the agent does not carry through from intention to finished action, of if the latter is badly implemented, then 'there is some fault in the practical reasoning, however excellent the deliberation'. ${ }^{95}$

\section{Learning from tragedy and the future of humanitarian intervention}

The question that haunts tragedies of the kind inherent in humanitarian interventions is how to know what is 'right' on particular occasions and how to act on that knowledge. Both revolve around dilemmas that emerge as a result of clashing values and duties, and both are concerned about how to act - relatively quickly - in the face of difficult moral problems. Here episteme (theoretical or scientific knowledge) is of little use, for human values and customs are temporally and culturally bound. What is required, therefore, is a form of wisdom that is able to guide us in morally complex spheres of life. This is summated by Vernant, who explains that 'On the one side, [tragedy] consists in taking counsel with oneself, weighting the for and against and doing the best one can to foresee the order of means and ends. On the other hand, it is to take a bet on the unknown and the incomprehensible and to take a risk on a terrain that remains impenetrable to you'.96

Phronesis involves 'flexibility, openness and improvisation'. ${ }^{97}$ In tragedy, these are essential qualities to confront the moral and practical complexity of a situation where there is no one obvious course of action. This claim is implicit in Thucydides' account of the Peloponnesian War. For him, writing in the aftermath of this destructive war, miscalculations will always occur so long as human nature remains 
the same. And yet, as Lebow argues, why would Thucydides have invested decades in researching and writing his account of the war and labeling it at the outset as a 'possession for all times' if he considered that history was ineluctable with humans trapped forever in the jaws of fate?98 He must have believed that people have some control over their destinies. This is particularly striking in the last words of Book II, 65: 'So Pericles had more than enough reasons to predict that the city might easily outlast the Peloponnesians in this war'. The historian's underlying message is that the Athenians' tragic defeat in the war was not inevitable. Their leader Pericles was a man of practical wisdom par excellence and, as Thucydides puts it, 'as long as he was at the head of [Athens] in time of peace, he governed it with moderation and guarded it securely; and it was the greatest under him'. ${ }^{99}$ Had he not accidentally died from plague during the course of the war, his wisdom, intelligence and foresight could have reversed the outcome of the war and led Athens to victory. Instead, defeat was brought about by the miscalculations of subsequent leaders and brash decisions at crucial junctures of the war: leaders, in other words, who succumbed to the temptation of hubris and were incapable of acting wisely. If order depends on the moral qualities of leaders in the face of events, the kind of wisdom that is encapsulated in the concept of phronesis might prevent tragedies from happening, or at least reduce their baleful consequences.

\section{Common sense and 'superior' laws}

Aristotle's phronesis is based on a 'common sense' that is shared by humanity with regard to 'the things that are good or bad for man'. ${ }^{100}$ It acknowledges the existence of certain values that are eternal and 'superior' to civil law. These non-written laws are invoked by Antigone when she decides to give her brother a proper burial, but 
transgresses the decree issued by the king on behalf of the universal principle of the reverence for the dead: 'I never thought that your orders are so powerful that they give you as a mortal human the right to transgress the unwritten, eternal laws of the Gods'. ${ }^{101}$ These superior laws, it might be said, are those enshrined in the human conscience of all 'reasonable men'. ${ }^{102}$ When associated with Aristotle's phronesis, namely, discernment and good judgement, they allow us to act with courage in the face of the unexpected. In a given situation, it might seem that a virtuous or prudent person, one that listens to his or her innate common sense and emotions, would know intuitively what the more reasonable course of action is.

An enlightening example is that of the context following World War II. The redaction of the Universal Declaration of Human Rights as well as the Nuremberg Trials constituted exceptional kairos for the international community with considerable discussions about crimes that fell outside of civil law and yet were morally impossible to leave unpunished. The only guide for action in this instance was 'the conscience of all civilized men'. ${ }^{103}$ This example resonates with the 2001 doctrine of the 'Responsibility to Protect' and the establishment of the International Criminal Tribunal for the former Yugoslavia, which also derives from the 'innate' conscience of humankind in front of crimes abhorrent to humanity.

From this perspective, tragedy and progress are not necessarily mutually exclusive. Thucydides describes how great miscalculations occur along with their fatal consequences in order to better understand how tragedy shapes our present and, perhaps, help leaders avert them in the future. Of course, this is an ideal that will forever remain elusive, for immoderate behaviour is intrinsic to human nature. But it nevertheless leaves room for progress and improvement. The account of the Peloponnesian War, the Bosnian War and other tragedies provide us with a vantage 
point from which to reflect on present and future political choices and be more cautious (phronimos) in our everyday decisions. Anyone can yield to impulses, make mistakes and stumble into hamartia. But hubris - what Morgenthau referred to as the 'sin of pride' - should not blind us. ${ }^{104}$ Tragedies encourage us to be phronimos by bringing awareness of the fatal consequences that might result from human overconfidence and errors of judgement.

To solve a practical problem, normative ideals are of little use because they are ill suited to human affairs - that is to say, the realm of the uncertain and the contingent. A dogmatic approach to values in the face of practical problems might even become dangerous. One could say that while Antigone acknowledges the existence of 'superior' laws, she exhibits absolutely no prudence in her stubborn engagement. Her blind obedience to a 'superior' rule comes at the cost of endangering the civic order of the polis and produces terrible consequences for herself. Rather, the wisdom associated with phronesis invites the citizen and policymaker to embrace ideal values as guidelines for behaviour or a policy horizon rather than as unwavering rules to be obeyed at all costs. It offers a considered rather than dogmatic attitude toward rules and values such as dignity, liberty or equality, and invites humans to think critically and creatively about their environment.

Contemporary conceptions of decision-making are often far removed from the kind of rationality that underpins phronesis. Bryan Garsten observes 'a crisis of confidence about citizens' capacity to exercise practical judgement in public deliberations'. ${ }^{105}$ The unyielding commitment to otherwise laudable values - or ideologies - can lead to dramatic consequences. But ignoring the emotions and 'superior laws' that lay at the heart of Aristotelian ideas of the presence of a common humanity in front of barbarity can be just as destructive. Paving a third way 
between idealism and Machiavellianism, Pericles as a man of practical wisdom, appears as a figure capable of displaying the astute political acumen, a sense of military strategy and flexibility to address the unforeseen, but also the knowledge of 'what is good or bad for man'. ${ }^{106}$

The concept of phronesis might prove useful to policymakers as a source of moral and policy guidance in the face of humanitarian pressures. It might also offer another benefit. As Benasayag and del Rey observed, never before has a society been so disciplined than it is today. ${ }^{107}$ In opposition to modern scepticism about human intuitions and emotions, the concept of phronesis fosters confidence and trust in the human ability to react in the face of uncertainty. A humanistic conception of tragedy integrates the practical dimension of phronesis as a form of wisdom that can restrain hubris and its likely consequences, but also invites proportionate and reasonable political action in the face of the violation of non-written, 'superior' values. It is grounded in the belief that human are flawed, but have also the innate ability to sense what the appropriate course of action is. In sum, the recognition of 'superior' values should be sustained by practical reason, both forming the 'intelligent heart' of men. ${ }^{108}$

\section{Conclusion}

Tragedy confronts us with the limitations of the human condition. It illustrates our frailties and vulnerability, reveals the contradictions of agency and sheds light on the complexities of existence. It highlights how choices are made without being able to adequately measure their consequences. It cautions against the danger associated with overconfidence. It warns against assuming that particular rules or conventions are universally applicable. Tragedy also underlines the complexity of moral 
imperatives, and how contradictory ethical demands often are. But, it also clarifies how self-awareness and wisdom can emerge from despair and suffering. For Sophocles, Euripides and Aeschylus, tragedy illustrates what it means to be human, both at the levels of the individual and the collective. The hallmark of the ancient genre is the recognition that misfortune is inevitable. Tragedy warns us that as humans, with limited knowledge and partial perceptions, our grip on the reality of ourselves can only be provisional and incomplete.

In Greek thought, literature preceded history and informed philosophy. For this reason Aristotle envisioned tragedy as a theoretical foundation for public institutions. Employing a similar line of thought, this study maintains that positioning tragedy as a conceptual tool fosters a more sophisticated understanding of ethical dilemmas as they emerge in international affairs. The analysis has also shown how humanitarian intervention during the Bosnian war illuminates the epistemological role of tragedy in political life. Bosnia was a 'tragedy' in the classical sense in that the circumstances in which moral dilemmas arose combined with the bubris and flaws of the protagonists leading to destructive and unintended outcomes.

If tragedy enables a more critical appreciation to guide political action, especially towards armed humanitarian intervention, it is to enrich our vocabulary, and inform moral reflection. It is also to make sense of the fears and emotions that are involved in complex moral situations but which are usually expressed awkwardly and hesitantly in the public sphere. Tragedy shows us not only how moral dilemmas emerge but can, to a useful degree, prescribe how to respond to them. Indeed, accepting the tragic dimension of humanitarian intervention should not lead towards a reflex passivity and disengagement towards the world's problems, for tragedy does not rhyme with fatalism. Rather, the tragedian's universe is characterised by the 
understanding of the indeterminacy of human ethical agency, not the evasion of action.

More broadly, tragedy teaches us to reason through both moral and practical evaluation, however contradictory the two may seem. Some problems have no answers that do not involve some degree of harm. Yet, it is equally true that sometimes a course of action must be chosen even though it will be the lesser of two evils. Aspiring to high-minded ideals is laudable but the unyielding commitment to them can come at a cost. These tensions are inherent in humanitarian intervention and cannot be wished away. Instead of trying to overcome them or ignoring them as Agamemnon did in the Oresteia, as the international community did in Bosnia policy-makers should recognise this tragic dimension and think 'prudently' for ways to reconcile ideals with political action and progress. This means having the courage to act in front of crimes that outrage the conscience of humanity but at the same time remaining aware of the inherent limitations of the human condition itself.

The Greek concept of phronesis relates precisely to qualities of practical intelligence, considering the circumstances and discerning the appropriate course of action. It also resonates with Perelman's notion of the universal audience, which refers to the conscience of all reasonable people as well as their intuitive knowledge of 'superior' values and what is inherently good. As we sought to show, a bumanistic approach to tragedy can assist in reacting to ethical dilemmas and the sheer uncertainty of the human realm by enabling the actors to judge with more insight and act with more foresight. It would allow policy-makers to better grasp the tragic aporias of politics and humanitarian intervention, and thus enable a more careful and perceptive practice of it. In that respect, an understanding of tragedy is perhaps the beginning of political wisdom. 
1. Richard Ned Lebow, The Tragic Vision of Politics: Ethics, Interests and Order (Cambridge: Cambridge University Press 2003), p. 24

2. Rebecca Bushnell, Tragedy: A Short Introduction (Oxford: Blackwell, 2008), p. 1.

3. Jean-Pierre Vernant, 'Tensions and Ambiguities in Greek Tragedy', in Jean-Pierre Vernant and Pierre Vidal-Naquet (eds.), Myth and Tragedy in Ancient Greece (New York: Zone, 1990), pp. 32-33.

${ }^{4}$. Aristotle (1985), Poetics, trans. Kenneth A. Telford (London: University Press of America), pp. 1452A 10-1452b 10.

5. Toni Erskine and Richard Ned Lebow, 'Understanding Tragedy and Understanding International Relations', in Toni Erskine and Richard Ned Lebow (eds.), Tragedy and International Relations (New York: Palgrave Macmillan, 2012), p. 4.

${ }^{6}$. See Michael W. Doyle, Ways of War and Peace: Realism, Liberalism and Socialism (New York: Norton, 1997).

7. Martha C. Nussbaum, 'Philosophy and Literature', in D. Selley (ed.), The Cambridge Companion to Greek and Roman Philosophy (Cambridge: Cambridge University Press, 2003), p. 25.

8. See for example John J. Mearsheimer, The Tragedy of Great Power Politics (New York: Norton, 2001); Hans J. Morgenthau, Politics Among Nations: The Struggle for Power and Peace (New York: Alfred Knopf, 1985); Peter J. Euben, Greek Tragedy and Political Theory (Berkeley and Los Angeles: University of California Press, 1986); Peter J. Euben, The Tragedy of Political Theory: The Road Not Taken (Princeton: Princeton University Press, 1990).

9. Chris Brown, "Tragedy, “Tragic Choices" and Contemporary International Political Theory', in Erskine and Lebow (2012), pp. 75-85.

10. Mervyn Frost, 'Tragedy, Ethics and International Relations', in Erskine and Lebow (2012), p. 39.

11. See Robert D. Kaplan, Balkan Ghosts:

12. Aristotle, Nicomachean Ethics, trans. David Ross (Oxford: Oxford University Press, 2009), p. VI 1140b.

13. Jean-Pierre Vernant and Pierre Vidal-Naquet, Oedipe et ses mythes (Paris: Editions complexes, 1988), pp. 1-22.

14 On this point, see Nathan Spiegel (1971), 'On Aristotle's Definition of Tragedy', Revue belge de philologie et d'histoire, 49: 1 (1971), pp. 14-30. See also Simon Critchley, Tragedy: The Greeks and Us (New York: Pantheon, 2019).

15 Peter Euben, The Tragedy of Political Theory: The Road Not Taken (Princeton: Princeton University Press, 1990). 
16. Frost (2012), pp. 27-28.

17. Nussbaum (2003), pp. 220-222.

18. Frost, (2012), p. 27.

19. Erskine and Lebow (2012), p. 3.

20. Frost (2012), pp. 21-43.

21. Morgenthau (1985), p. 11.

22. Lebow, The Tragic Vision of Politics, p. 336.

23. Tracy B. Strong, 'Nietzsche and Questions of Tragedy, Tyranny and International Relations', in Erskine and Lebow (2012), pp. 145.

24. Aristotle (1985), 1447a-1449b.

25. Aristotle (1985), 1453a 1-20.

26. Erskine and Lebow (2012), p. 4.

27. Vernant (1988), pp. 32-33.

28. Euben (1986), p. 29.

29. Erskine and Lebow (2012), p. 8.

30. Adrian Poole, Tragedy: Shakespeare and the Greek Example (New York: Blackwell, 1987), p. 12.

31. See Euben (1986), pp. 6-9.

32. Nicholas Rengger, 'Tragedy or Scepticism? Defending the Anti-Pelagian Mind in World Politics', in Erskine and Lebow (2012), pp. 54.

33. Bernard Williams, Shame and Necessity (Berkeley and Los Angeles: University of California Press, 1993), p. 164.

34. James Mayall, 'Tragedy, Progress and the International Order', in Erskine and Lebow (2012), pp. 46.

35. Brown (2012), p. 76.

36. J.L Holzgrefe and Robert O. Keohane, Humanitarian Intervention: Ethical, Legal and Political Dilemmas (Cambridge: Cambridge University Press, 2003), p. 18.

37. See Gary Bass, Freedom's Battle (New York: Knopf, 2008), pp. 30-36; Stephen Wertheim, 'A Solution from Hell: The United States and the Rise of Humanitarian Intervention, 1991-2003', Journal of Genocide Research, 12: 3-4 (2010), p. 150.

38. Holzgrefe and Keohane (2003), p. 1. 
39. See the United Nations Charter, Article 2 (4), available at: \{http://www.un.org/ en/charter-united-nations/ $\}$.

40. Eric A. Heinze, Waging Humanitarian War: The Ethics, Law, and Politics of Humanitarian Intervention (Albany: SUNY Press, 2009), p. 16.

41. International Commission on Intervention and State Sovereignty, The

Responsibility to Protect (Ottawa: International Development Research Centre, 2001).

42. See UN General Assembly, World Summit Outcome Document (2005), paras. 138 and 139, available at: \{http://www.un.org/en/development/desa/population/

migration/generalassembly/docs/globalcompact/A_RES_60_1.pdf\}.

43. Heinze (2009), p. 15.

44. Heinze (2009), pp. 15-32.

45 Brown (2012), p. 80.

46. Brown (2012), p. 84.

47. Charles R. Beitz, Political Theory and International Relations (Princeton, NJ:

Princeton University Press, 1999).

48. Michael Walzer, 'Political Action: The Problem of Dirty Hands', Philosophy and Public Affairs, 2: 2, pp. 160-180.

49. Brown (2012), pp. 80-81.

${ }^{50}$. Lara J. Nettelfield, 'Research and Repercussions of Death Tolls: The Case of the Bosnian Book of the Dead', in Peter Andreas and Kelly M. Greenhill (eds.), Sex, Drugs and Body Counts: The Politics of Numbers in Global Crime and Conflict (Ithaca: Cornell University Press, 2010), pp. 159-187.

51. See Michael Barnett, 'Humanitarianism Transformed', Political Sciences and Politics, 4: 3 (2005), pp. 723-740; Sherene H. Razack, Dark Threats and White Knights: The Somalia Affair, Peacekeeping, and the New Imperialism (Toronto: University of Toronto Press, 2004).

52. Susan L. Woodward, Balkan Tragedy: Chaos and Dissolution After the Cold War (Washington, DC: Brookings Institution Press, 1995), p. 11.

53. A detailed account of the war and some of the key interpretations surrounding its unfolding can be found in Woodward (1995), Campbell (1998) and Kaplan (1993).

54. Mihailo Crnobrnja, The Yugoslav Drama (London: Tauris, 1994), p. 4.

55. See Misha Glenny, The Fall of Yugoslavia (London: Penguin, 1996), pp. 188-180.

56. Sophocles, Oedipus Tyrannos, II, 7-9 in The Three Theban Plays: Antigone, Oedipus the King, Oedipus at Colonus, trans. Robert Fagles (New York: Penguin Books, 1984). 
57. D.R. Dawe, 'Some Reflections on Ate and Hamartia', Harvard Studies in Classical Philology, 72 (1968), pp. 89-123; Erskine and Lebow (2012), p. 14.

58. Woodward (1995), p. 148.

59. Woodward (1995), p. 148.

60. Woodward (1995), p. 149.

61. Edgar O’Ballance, Civil War in Bosnia, 1992-94 (New York: St Martin Press, 1995), p. xii.

62. Brown (2012), p. 83

63. Kirsten Young, 'UNHCR and ICRC in the former Yugoslavia: BosniaHerzegovina', International Review of the Red Cross, 83: 843 (2001), p. 802.

${ }^{64}$. Woodward (1995), p. 11.

65. Kurt Mills, 'United Nations Intervention in Refugee Crises after the Cold War', International Politics, 35: 4 (1998), p 406.

66. Ivana Nizich, War Crimes in Bosnia-Herzegovina (Helsinki: Human Rights Watch, 1992), p. 124

67. Quoted in Young (2001), p. 796.

68. Laura Silber and Allan Little, The Death of Yugoslavia (London: Penguin, 1995), p. 303.

69. Dick A. Leurdijk, The United Nations and NATO in the Former Yugoslavia (The Hague: Netherland Atlantic Commission, 1996), p. 44.

70. Quoted in Stuart Gordon (2001), 'A Recipe for Making Safe Areas Unsafe', in Stuart Gordon and Francis Toase (eds.), Aspects of Peacekeeping (London: Frank Cass, 2001), p. 217.

71. Jan W. Honig and Norbert Both, Srebrenica: Record of a War Crime (London: Penguin, 1996), p. 178.

72. See Dawe (1968), pp. 89-123.

73. Richard Ned Lebow, A Cultural Theory of International Relations (Cambridge: Cambridge University Press, 2008), p. 99

74. Honig and Both (1996), p. 183.

75. Honig and Both (1996), p. 183.

76. Lindsey Hilsum, 'A Village Tyrant Spells Out His Dreams for the Serbs', The Independent (16 June 1996), available at: \{https://www.independent.co.uk/news/ world/a-village-tyrant-spells-out-his-dream-for-the-serbs-1337312.html\} accessed 12 September 2019. 
77. See Peter A. French, The Virtues of Vengeance (Lawrence: University Press of Kansas, 2001).

78. Michael Ignatieff, Empire Lite: Nation-Building in Bosnia, Kosovo and Afghanistan (New York: Vintage, 2003), p. 321.

79. See Charles-Philippe David, 'Alice in Wonderland Meets Frankenstein:

Constructivism, Realism and Peacebuilding in Bosnia', Contemporary Security Policy, 22: 1 (2001), pp. 1-30.

${ }^{80}$. The ICTY is a body of the UN established by Resolution 827 of the UN Security Council and located in The Hague. Since the Tribunal started its work, it has indicted 161 individuals. See the ICTY website http://www.icty.org.

81. United Nations, Report of the Secretary General Pursuant to General Assembly Resolution 53/35: The Fall of Srebrenica, no. A/53/549 (1999), p. 108.

82. Benjamin A. Valentino, 'The True Cost of Humanitarian Intervention. The Hard Truth Behind a Noble Notion', Foreign Affairs, 90: 6 (2011), pp. 61-73

83. Catherine Lu, 'Tragedies and International Relations', Toni Erskine and Lebow (2012), pp. 159-160.

84. Quoted in Joe Western, Selling Intervention and War: The Presidency, The Media, and the American Public (Baltimore, Maryland: John Hopkins University Press, 2005), p. 160.

85. Lane Warren and Ann M. Lane, 'The Politics of Antigone', in Peter Euben (ed.), Greek Tragedy and Political Theory (Berkeley: University of California Press, 1986), p 53.

86. Aristotle (2009), 1138b ff.

87. Aristotle (2009), 1140a35.

88. Bent Flyvbjerg, Making Social Sciences Matter: Why Social Inquiry Fails and How It Can Succeed Again, trans. Steven Samson (Cambridge: Cambridge University

Press, 2002), p. 4.

${ }^{89}$. Aristotle (2009), IV, 1140b.

${ }^{90}$. Pierre Aubenque, La prudence chez Aristote (Paris: PUF, 1993), p. 63

91. Aristotle (2009), IV, 1140b1.

92. Aubenque (1993), p. 63.

93. Daniel Westberg, Right Practical Reason: Aristotle, Action, and Prudence in Aquinas (New York: Oxford University Press, 1994)

94. John Wall, 'Phronesis, Poetics and Moral Creativity', Ethical Theory and Moral Practice, 6: 3 (2003), p. 317. 
95. Westberg (1994), p. 5.

96. Williams (1993), p. 19.

97. Joesph Dunne, Back to the Rough Ground: 'Phronesis' and 'Techne' in Modern Philosophy and in Aristotle (Notre Dame: University of Notre Dame Press, 1993), p. 245.

98. Lebow, 'Tragedy, Politics and Political Science' in Erskine and Lebow (2012), p. 68.

99. Thucydides, History of the Peloponnesian War, trans. Martin Hammond (Oxford: Oxford University Press, 2009), p. 65.

${ }^{100}$. Aristotle (2009), p. VI, 1140b.

101. Sophocles (1984), pp. 452-457.

102. This is encapsulated in the notion of 'universal audience' by Chaïm Perelman and Lucie Olbrechts-Tyteca as a virtual concept referring to the conscience of 'all reasonable beings', namely, the entire set of educated and reasonable people across the broadest human spectrum possible. For Perelman, there are non-written laws on which all reasonable being agree, and the validity of a statement in the realm of human affairs has more to do with what is 'reasonable' in any particular case than with truth or logic. Of crucial importance in Perelman's concept of universal audience is the fact that values have no fixed meaning: principles such as 'equality', 'justice' or 'dignity' are necessarily vague and must remain so. See Chaïm Perelman and Lucie Olbrechts-Tyteca, The New Rhetoric. A Treatise on Argumentation (London: University of Notre Dame Press, 1971).

103. Chaïm Perelman, 'Can the Rights of Man be Founded?' in Alan S. Rosembaum (ed.), The Philosophy of Human Rights: International Perspectives (Westport, Conn.: Greenwood Press, 1980), p 47.

104. Morgenthau (1985), p. 11.

105. Bryan Garsten, Saving Persuasion: A Defense of Rhetoric and Judgement (Cambridge; London: Harvard University Press, 2006), p. 4.

106. Aristotle (2009), IV1140; Aubenque (1993), p. 63.

107. Miguel Benasayag and Angélique del Rey, Éloge du conflit (Paris: La Découverte, 2007), p. 184.

108. Emmanuelle Danblon, L’homme rhétorique (Paris: Cerf/Humanités, 2013), p. 192. 